Research Article

\title{
Population Structure and Regeneration Status of Woody Species in Kenech Forest, Southwest Ethiopia
}

\author{
Sewale Balemlay and Mammo Siraj \\ Biology Department, College of Natural and Computational Sciences, Ambo University, Ambo, Ethiopia \\ Correspondence should be addressed to Mammo Siraj; sirajmammo@gmail.com
}

Received 4 November 2020; Revised 22 August 2021; Accepted 12 September 2021; Published 6 October 2021

Academic Editor: Nikolaos D. Hasanagas

Copyright ( 2021 Sewale Balemlay and Mammo Siraj. This is an open access article distributed under the Creative Commons Attribution License, which permits unrestricted use, distribution, and reproduction in any medium, provided the original work is properly cited.

\begin{abstract}
Understanding the structural pattern and regeneration status of tree species is an important measure taken to assess the vegetation dynamics and their destruction factors species as well as management history and ecology of the forest. This study was conducted with the objective to assess the species diversity, structure, and regeneration status of woody species in Kenech natural forest, Ethiopia. Systematic random sampling method was employed as a sampling design for the collection of vegetation data. Accordingly, 40 plots of $20 \mathrm{~m} \times 20 \mathrm{~m}$ were laid at every $100 \mathrm{~m}$ along four parallel transect lines following altitudinal gradient. Any woody species of trees and shrubs with the diameter at breast height $(\mathrm{DBH}) \geq 2.5 \mathrm{~cm}$ was measured at $1.5 \mathrm{~m}$ from the ground. In each sample plots, all woody species seedling, sapling, and mature woody species were counted and recorded. A total of 80 plant species categorized into 67 genera and 28 families were recorded and identified, for description and analysis of vegetation structure. Structural analysis of the Kenech natural forest revealed a density of $840 \mathrm{stems} / \mathrm{ha}$ and a total basal area of $56.8 \mathrm{~m} / \mathrm{ha}$. About $80.36 \%$ of the individuals are found in the first two classes $(2.5-10$ and $10-20 \mathrm{~cm})$. The general pattern of DBH class distribution of woody species in the study area revealed an inverted J shape indicating the presence of a high density of trees in the lower DBH class than in the higher. The most dominant tree species relatively with the highest importance values recorded in the area were Pouteria adolfi-friedericii, Podocarpus falcatus, Celtis africana, Mimusops kummel, Pyschotria orophila, and Olea capensis subsp. macrocarpa. Forty-two species (64.61\%) were represented by both seedling and sapling class, whereas 9 species (13.84\%) were not regenerating.
\end{abstract}

\section{Introduction}

Ethiopia is a country characterized by highly diversified physiographic, altitudinal, climatic, and edaphic with a wide range of habitats and vegetation types which are rich in endemic flora and fauna $[1,2]$. Ethiopia has been designated a Global 200, an ecoregion of global importance for biodiversity conservation [3]. The number of species of higher vascular plants is about 6027 , of which about $10 \%$ are endemic to the country $[4,5]$. This high number of plant species results from the wide variation in climate, geology, and terrain working on different time scales $[6,7]$ and past historical events. Much of its floristic wealth is reflected in the fact that Ethiopia is one of the Vavilov's centers of origin and/or diversity for many plants [8].
Despite the presence of high floristic composition and endemic species, deforestation is occurring in different parts of Ethiopia at an alarming rate and threatening much of the country's unique biodiversity [9] and the livelihood of the local community. In Ethiopia, environmental degradation and deforestation have been taking place for hundreds of years throughout the different parts of the country [10]. According to Hundera and Deboch [11], the forests in the entire country declined from the original climax $35 \%$ to $16 \%$ in $1952,3.6 \%$ by $1980,2.6 \%$ by 1987 , and an estimated $2.4 \%$ in 1992; this is due to anthropogenic-related factors.

Deforestation and degradation are the causes of forest cover loss in Ethiopia which has its origin in a cascade of events [12]. The Geometric population growth of Ethiopia resulted in rural demand for agricultural lands [13], which in 
turn led to the expansion of cultivated fields at the expense of the forest and other land use types such as grazing and shrub lands $[14,15]$. The Ethiopian vegetations, particularly the forest resources, are under severe pressure as a consequence of inhabitants need of more farm land for agriculture and grazing lands for their livestock. In Ethiopia, several factors have been mentioned as the causes of deforestation such as increasingly intensive use of land for agricultural and livestock production, tree cutting for fuel wood and construction materials, inappropriate conservation approaches, and lack of awareness [12, 16-18].

In Ethiopia, most of the remaining patches of fragmented forests are confined to the south and the southwestern parts of the country which are less accessible [19]. However, nowadays, the remnant natural forests in these areas are also continuously threatened by anthropogenicassociated factors and the existing ones are in a secondary state of development [20].

Plant population structure shows whether or not the population has a stable distribution that allows continuous regeneration to take place [21]. Knowledge on the population density of seedlings, saplings, and adults is important as it determines the population structure and status of regeneration of any forest community [22]. The future composition of forests depends on potential reproduction and recruitment as regeneration status of tree species within a forest stand in space and time [23-25].

Systematic field survey of flora and fauna is a prerequisite for developing effective conservation programs and its implementation [5]. Thus, the study of vegetation structure and their regeneration status of the tropical forest become more imperative in the face of the ever-increasing threat to the forest ecosystem. According to Segawa and Nkuutu [26], the knowledge of the population structure of woody plant species and their natural regeneration status analysis of the given forest becomes prerequisite for forest conservation and management and conservation strategies of biodiversity and its ecosystem services [26, 27]. Knowledge of population structure of woody species and their natural regeneration status analysis of the forest resources is also useful in identifying important elements of plant diversity, protecting threatened and economic species, and monitoring the status of forest $[26,28]$.

The density value of seedlings and saplings are considered as an indicator of regeneration potential of the species [29] in which the presence of good regeneration indicates the suitability of a species to the environment, which is in turn affected by climatic factors and biotic interference influence [30]. The successful regeneration of woody tree species is mainly dependent on a function of three major components: (i) their ability to initiate new seedlings, (ii) the survival ability of seedlings and saplings, and (iii) the growth ability of seedlings and saplings [31].

Several scholars have conducted various studies in different parts of our country Ethiopia on population dynamics and regeneration statues of remnant forest patches [32-37]. The results of these works provide relevant information on the regeneration status of many tree and shrub species, which is of paramount importance to undertake appropriate conservation and management measures.
Kenech natural forest is among the few remaining tropical Afromontane forest patches in Ethiopia, where one finds a high number of plant species diversity with remarkable vegetation stands. Although Kenech natural forest has been designated as an NFPA, little conservation attention was given. But up to now, there is no study conducted on vegetative structure and regeneration status which is vital to call for immediate and timely scientific interventions to uphold the conservation of this natural high forest. It is important to study the population structure and regeneration potentials of different natural forest tree species of Kenech natural forest to assess the trends of vegetation in the future. Hence, this study was conducted with the following specific objectives of the study which were (i) to evaluate the natural regeneration status of woody species of the forest and (ii) to describe the population structure in terms of species in the Kenech natural forest.

\section{Materials and Methods}

2.1. Description of the Study Site. Kenech natural forest is located in Chena district, Kefa Zone, South Nations and Nationalities Regional State, Ethiopia (Figure 1). The forest is among the National Forest Priority Areas (NFPAs) in the country [38]. The forest lies approximately between $7^{\circ} 16^{\prime} \mathrm{N}$ latitude and $35^{\circ} 11^{\prime} \mathrm{E}$ longitude in Chena district, $30 \mathrm{~km}$ south-west of Bonga which is located at about $540 \mathrm{~km}$ south west of Addis Ababa, the capital city. This forest is located along with altitudinal ranges between 1700 and $2400 \mathrm{~m}$ a.s.1 and covers an area of about 10.8 ha SNNPR Agricultural Bureau Personal Communication.

Topographically, the forest is generally characterized by rough topography with undulating plain, hills, slopes, deep valley, gorges, escarpments, and dissected plateaus. Some perennial rivers such as Kenech river, Kurkusha river, Decha river, Wanjale river, and Shishnda river are flowing into Donbra river by crossing the forest, all of which emerge from the highlands.

The temperature and rainfall data for this study was obtained from Bonga Meteorological Station from 2005 to 2019 [39]. The distribution of rainfall is unimodal, characterized by a prolonged wet season from June to September (big rain) and a short dry spell showers from mid-February to April. There is a long dry period from October to the end of February [40]. Based on 15-year data, the mean annual rainfall in the study area is about $1566 \mathrm{~mm}$, rainfall peak period between May and October, and decreasing in November and December with little or no rainfall in January and February.

The mean annual temperature is about $16.6^{\circ} \mathrm{C}$ and the mean minimum temperature is $10.78^{\circ} \mathrm{C}$, whereas the mean maximum temperature is $22.32^{\circ} \mathrm{C}$. There is a slight temperature difference throughout the year. The hottest months are from February to May maximum temperature recorded is about $24.6^{\circ} \mathrm{C}$ (in April/May), and the coldest months are from July to December with the mean minimum temperature $9.8^{\circ} \mathrm{C}$ (in December). Based on altitudinal variations, Chena district has three agroclimatic zones which correspond to the traditional classification systems: $43 \%$ Dega 


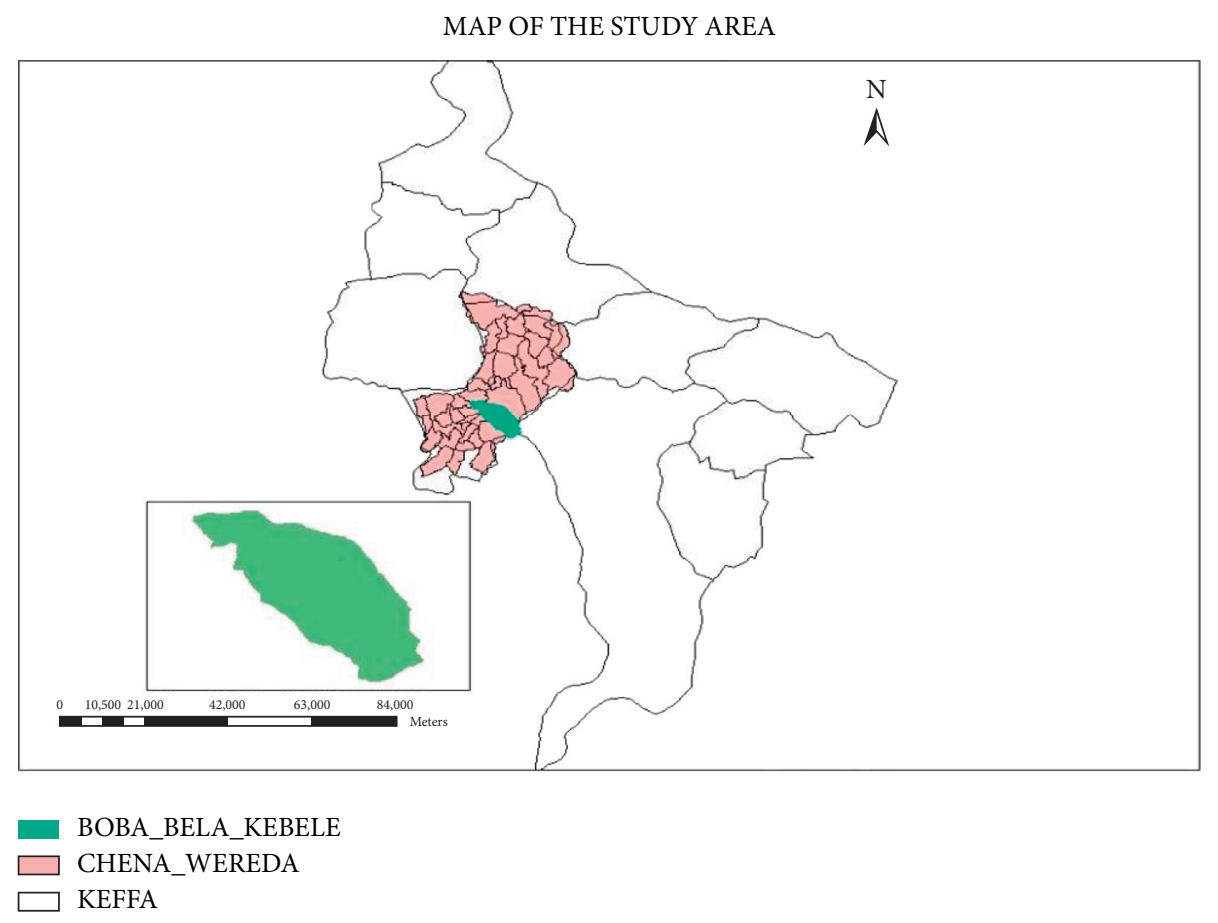

Figure 1: Map of the study area.

(2500-3500 m), 55.56\% WoinaDega $(1500-2500 \mathrm{~m})$, and $1.24 \%$ Kola (500-1500 m) [40].

The geology and soils of Ethiopia fall within the geological structural units of the Horn of Africa [41]. Precambrian rocks from the basement rock of the southwestern plateau overly by tertiary basal traps lava flow which is generally gently dipping to flat [41]. In south-western Ethiopia, soils are deep and belong to the Order Oxisols and Ultisols; most common forest soils in Ethiopia are red or brownish ferrisols derived from volcanic parent material [42]. Oxisols/Rhodic Ferrasols occur in the $1500-2000 \mathrm{~mm}$ annual rainfall of western and southwestern Oromia and SNNPR as in Wollega, Ilu-babor, Jimma, and Kaffa [43].

Like other parts of the country, mixed cultivation of livestock rearing and crop production, subsistence agriculture is the main economic development of the community, of which coffee and honey production are also practiced in the forest area.

According to population and housing census reported by the CSA [44], the total population of Chena district was 76,162; of these, 73,983 and 2,179 were rural and urban, respectively. Similarly, 38,256 are females and 37,906 are males in the district. In each, 36,811 are males and 37,172 are females in rural, whereas 1,095 are males and 1,084 are females in the urban area.

The south-western forests of Ethiopia are characterized as moist montane forest ecosystems [45, 46]. The species listed in other moist montane forest ecosystems by different researchers such as $[16,38,46,47]$ are also found in the Kenech natural forest. The Kenech natural forest is characterized by the following common species Pouteria adolfifriedericii, Mimusops kummel, Podocarpus falcatus, Galiniera saxifraga, Syzygium guineense spp. afromontanum,
Prunus africana, Albizia gummifera, Croton macrostachyus, Cassipourea malosana, Ekebergia capensis, Ficus sur, Maesa lanceolata, Teclea nobilis, and Bersama abyssinica.

\subsection{Methods}

2.2.1. Sampling Design. To collect the woody species vegetation data on population structure and regeneration, systematic sampling design, with random starting points, was applied following Kent [48] and Kent and Coker [49]. A total of four transect lines were arranged from following altitudinal difference in the sampling sites and laid at a distance of $200 \mathrm{~m}$ from each other. Sample plots of $20 \mathrm{~m} \times 20 \mathrm{~m}$ were taken along each transect, at a distance of $100 \mathrm{~m}$ from one another.

\subsubsection{Reconnaissance Survey and Structural Vegetation Data} Collection. A field reconnaissance survey of the vegetation area was executed in the first week of November 2018, to obtain an overview of the site conditions, to collect information on accessibility, and to identify sampling design. Following this, systematic sampling methods for vegetation data collection were selected. Each sampling site was identified on the ground by using the navigation facility of GPS apparatus and later modifies accordingly in the area of investigation.

The data was collected from March 26 to April 10, 2019, using plots each with the size of $20 \mathrm{~m} \times 20 \mathrm{~m}\left(400 \mathrm{~m}^{2}\right)$ for trees and shrubs. Sapling and seedlings data were collected using subplots of $10 \mathrm{~m} \times 10 \mathrm{~m}\left(100 \mathrm{~m}^{2}\right)$ and $5 \mathrm{~m} \times 5 \mathrm{~m}$ $\left(25 \mathrm{~m}^{2}\right)$ inside the main plots, respectively. A total of 40 plots were sampled, and specimens were collected from the study 
area. All individuals of trees and shrubs at each of the plot established with a diameter at breast height $(\mathrm{DBH})>2.5 \mathrm{~cm}$ and height $>1.5 \mathrm{~m}$, and abundance was counted and their circumference (diameter) and height was recorded following Ayalew et al. [50]. Individuals with DBH less than $2 \mathrm{~cm}$ and heights less than 1.5 were counted as seedling and sapling.

All the woody plant species encountered in each sample plot were recorded using their names. These specimens were identified following the published volumes of flora of Ethiopia and Eritrea Volume II-VIII, consulting with experts and authenticated specimens. Species occurring outside the plot were also collected and identified to produce a comprehensive list of the plant species diversity of the study area.

2.2.3. Analysis of the Vegetation Structure. All woody species were recorded in all the 40 plots and used in the analysis of the vegetation structure. The collected vegetation data were entered into Microsoft Excel office, and subsequent analyses of the data were performed. For description of the vegetation structure of the study area basal area, stem density, diameter at breast height $(\mathrm{DBH})$, species population structure, and IVI were used. The analysis of population structure was made by comparing the distribution of diameter classes. Bar graphs were developed using the $\mathrm{DBH}$ versus density of individuals for nine arbitraryDBH classes constructed following Hundera et al. [51] $(1=2.1-10,2=10.1-20$, $3=20.1-30, \quad 4=30.1-40, \quad 5=40.1-50, \quad 6=50.1-60$, $7=60.1-70,8=70.1-80,9 \geq 80 \mathrm{~cm})$.

According to Kuma and Shibru [52], the structural parameters can be analyzed using the following formula:

(1) Importance value $=$ relative density + relative frequency + relative dominance

(2) $\mathrm{SIV}=$ relative density $(\mathrm{RD})+$ relative dominance $(\mathrm{RDO})+$ relative frequency

(3) Density $=$ (number of individuals of species/area sampled)

(4) $\mathrm{RD}=$ (number of all individuals of a species /total number of all individuals of the sample) $\times 100$

(5) $\mathrm{RDO}=($ basal area of a species /total basal area of the sample) $\times 100$

(6) $\mathrm{RF}=$ (the number of plots where a species occur /total occurrence for all species of the sample) $\times 100$

(7) $d=C / \pi$

(8) Basal area $=\pi d^{2} / 4$, where $d=$ diameter at breast height $(\mathrm{DBH}) \pi=3.14$

2.2.4. Regeneration Data Analysis. The status of regeneration of a given species in the forest can be analyzed by comparing the number of seedling with sapling and sapling with matured tree data $[25,30,53-55]$. Accordingly, the regeneration status of the forest was assessed using the following categories.

(1) "Good" regeneration, if present in seedling $>$ sapling $>$ mature tree
(2) "Fair" regeneration, if present in seedling $>$ sapling $<$ mature tree

(3) "Poor" regeneration, if a species survives only in the sapling stage, but not as seedlings (even though saplings may be less than, more than, or equal to mature)

(4) "None," if a species is absent both in sapling and seedling stages, but present as mature

(5) "New," if a species has no mature, but only sapling and/or seedling stages

For the purpose of this study, seedling, saplings, and mature trees/shrubs were defined as plants with heights less than $1 \mathrm{~m}, 1-3 \mathrm{~m}$, and greater than $3 \mathrm{~m}$ respectively.

\section{Results and Discussion}

3.1. Floristic Composition of Woody Species. A total of 80 woody species of vascular plants belonging to 67 genera and 28 families were recorded and identified from the protected Kenech natural vegetation. The most dominant 6 families of woody plant species were Euphorbiaceae, representing (10\%) 8 species in 7 genera; Fabaceae $(8.75), 7$ species in 6 genera; Asteraceae (8.75), 7 species in 4 genera; and Rubiaceae (7.5) 6 species in 4 genera, while Lamiaceae and Oleaceae each represented by (5\%) 4 species (Table 1).

The life form distribution of these species was 35 (43.21\%) trees, $33(40.74 \%)$ shrubs, 9 lianas (11.11\%), and 3 climbers 3 (3.57\%) (Figure 2).

\subsection{Analysis of Vegetation Structure}

3.2.1. Density Distribution of Plant Species. According to Kacholi [56], forest structure can be described in terms of tree density (stems/ha), basal area $\left(\mathrm{m}^{2} / \mathrm{ha}\right)$, and size class distributions (SCDs). A total of 1344 individuals (840 stem/ ha) were counted with $\mathrm{DBH}>2.5 \mathrm{~cm}$ within sampled plots which is higher than that of Washa forest, 698.8 stems.ha ${ }^{-1}$ [57]; Kafta Sheraro National Park, 466 individuals.ha ${ }^{-1}$ [37]; Babile Elephant Sanctuary: 1319 stems $\cdot h^{-1}$ [58]; Nechisar National Park: 887 stems.ha ${ }^{-1}$ [59]. However, lower Chilimo forest: 3328.47 individuals $\mathrm{ha}^{-1}$ [25], Sire Beggo: 1845 stems $\cdot \mathrm{ha}^{-1}[60]$, and Gedam and Abebaye: 3001 stems $\cdot \mathrm{ha}^{-1}$ [61]. Of these woody species in the forest, Croton macrostachyus, Podocarpus falcatus, Galiniera saxifrage, and Prunus africana contributed to the largest proportion of individuals. The analysis of density showed that $42.2 \%$ of the total density comprises four species, namely, Croton macrostachytus was the dominant species in the forest comprising $16.45 \%$ (138.75 individuals $\mathrm{ha}^{-}$) followed by Ekebergia capensis (11.69\%) (98.13 individuals $\mathrm{ha}^{-1}$ ) and Prunus africana (7.23\%) (60.63 individuals ha ${ }^{-1}$ ) (Table 2).

The total density of woody species was 304 stems per ha for $\mathrm{DBH}>10 \mathrm{~cm}$ and 165 individuals per ha for $\mathrm{DBH}$ $>20 \mathrm{~cm}$. The ratio described as $\mathrm{a} / \mathrm{b}$ is taken as the measure of size class distribution [62]. Accordingly, for the Kenech natural forest, the ratio of individuals with $\mathrm{DBH}$ between 10 and $20 \mathrm{~cm}$ (a) to $\mathrm{DBH}>20 \mathrm{~cm}$ (b) was 1.8 , indicating slight 
TABLE 1: List of families with number of genera and species.

\begin{tabular}{lcccc}
\hline & Family & Genera & Species & \% of species \\
\hline 1 & Euphorbiaceae & 8 & 8 & 10.00 \\
2 & Asteraceae & 4 & 7 & 8.75 \\
3 & Fabaceae & 6 & 7 & 8.75 \\
4 & Rubiaceae & 6 & 6 & 7.50 \\
5 & Lamiaceae & 3 & 4 & 5.00 \\
6 & Oleaceae & 3 & 4 & 5.00 \\
7 & Celastraceae & 2 & 3 & 3.75 \\
8 & Combretaceae & 2 & 3 & 3.75 \\
9 & Malvaceae & 2 & 3 & 3.75 \\
10 & Moraceae & 1 & 3 & 3.75 \\
11 & Rutaceae & 3 & 3 & 3.75 \\
12 & Tiliaceae & 3 & 3 & 3.75 \\
13 & Acanthaceae & 2 & 2 & 2.50 \\
14 & Boraginaceae & 2 & 2 & 2.50 \\
15 & Dracaenaceae & 1 & 2 & 2.50 \\
16 & Ebenaceae & 2 & 2 & 2.50 \\
17 & Myrsinaceae & 2 & 2 & 2.50 \\
18 & Myrtaceae & 1 & 2 & 2.50 \\
19 & Rhamnaceae & 2 & 2 & 2.50 \\
20 & Rosaceae & 2 & 2 & 2.50 \\
21 & Sapotaceae & 2 & 2 & 2.50 \\
22 & Ulmaceae & 2 & 2 & 2.50 \\
23 & Meliaceae & 1 & 2 & 2.50 \\
24 & Menispermaceae & 1 & 1 & 1.25 \\
25 & Menispremaceae & 1 & 1 & 1.25 \\
26 & Urticaceae & 1 & 1 & 1.25 \\
27 & Verbenaceae & 1 & 1 & 1.25 \\
\hline
\end{tabular}

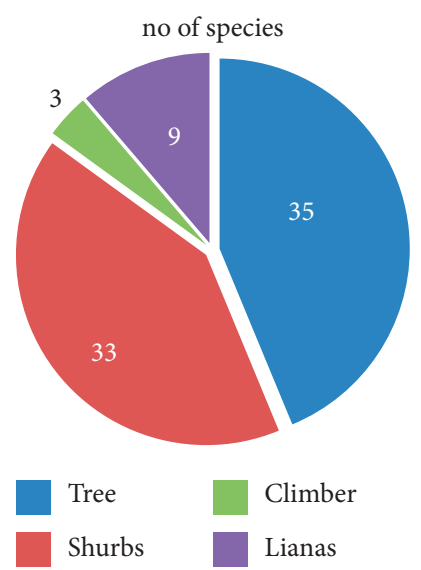

Figure 2: Growth form of woody species.

variation between the small-sized and large-sized stems, and most DBH were recorded in the lower DBH class size.

When comparing the ratio $(\mathrm{a} / \mathrm{b} \mathrm{DBH})$ of the Kenech forest to the other remnant patch of forests in Ethiopia, Kenech forest is relatively larger than that of Dodola, Berbere, Jibat, Alata-Bolale, Chato, Komto, and Kimphe Lafa forests but has a similar ratio with Jima forest. However, Yegof Masha Anderacha, Belete, Bibita, Menna Angetu, and Asabot forests have more $\mathrm{a} / \mathrm{b}$ ratio values than Kenech forest indicating that there is more predominance of trees in the lower DBH class in these forests than in Kenech forest (Table 3).
3.2.2. Frequency Distribution. Frequency has a great contribution in indicating heterogeneity and homogeneity of vegetation of a given species [73]. The frequency class distribution of woody species indicated that higher percentage of species were found at lower frequency classes with more than $89.23 \%$ of the species having a frequency value of less than $40 \%$ and only $10.77 \%$ of the species having a frequency value of $40-80 \%$ (Figure 3), indicating a relatively good floristic heterogeneity in the study area.

3.2.3. Diameter at Breast Height (DBH). The woody plant species in the study area were classified into nine $\mathrm{DBH}$ classes: $2-10 \mathrm{~cm}, 10.1-20 \mathrm{~cm}, 20.1-30 \mathrm{~cm}, \quad 30.1-40 \mathrm{~cm}$, $40.1-50 \mathrm{~cm}, 50.1-60 \mathrm{~cm}, 60.1-70 \mathrm{~cm}, 70.1-80 \mathrm{~cm}$, and $>80$ (Figure 4). About $80.36 \%$ of the individuals are found in the first two classes $(2.5-10$ and $10-20 \mathrm{~cm}$ ). The remaining 7 classes together accounted for about $19.64 \%$. The number of stems in DBH class less than $10 \mathrm{~cm}$ is $371 \mathrm{ha}^{-1}(44.16 \%)$, $304 \mathrm{ha}^{-1}$ (36.19\%) for DBH $10-20 \mathrm{~cm}$, and $165 \mathrm{ha}^{-1}(19.64 \%)$ for $\mathrm{DBH}>20 \mathrm{~cm}$. As the $\mathrm{DBH}$ classes size increases, the number of individuals gradually decrease beginning from 304 stems ha ${ }^{-1}$ in the second class down to 8 stems ha $^{-1}$ in the ninth DBH class. When viewed from the whole set of population structure, the distribution of all individuals in different size classes showed an inverted J shape for DBH classes (Figure 4).

The general pattern of DBH class distribution of woody species was calculated based on the sampled area, and the result showed the presence of an inverted J shape, suggesting a stable population structure. This is similar to those reported from other forests in Ethiopia [21, 45, 50,74-77] and other countries [78-80].

This type of population structure pattern is typically observed in natural undisturbed montane forests, with many small stems compared to few large ones [81], suggesting the presence of good reproduction and recruitment potential.

The majority of the species had the highest number of individuals in the lower DBH and low in the highest DBH classes. Such reversed J-shaped distribution pattern depicts that the forest is on the status of favorable regeneration and recruitment potential $[50,76]$. When the entire DBH class distribution of the forest is evaluated on a species basis, different population dynamics for different species were revealed.

Among all the individuals sampled in the Kenech natural forest, about $0.95 \%$ that attended a DBH greater than $80 \mathrm{~cm}$ belonged to the species of Podocarpus falcatus, Pouteria adolf-friedericii and Prunus africana. In addition, individuals of the abovementioned three species with a DBH of $165 \mathrm{~cm}, 130 \mathrm{~cm}$, and $105 \mathrm{~cm}$, respectively, were recorded in the Kenech natural forest.

The percentage distribution of DBH classes was $44.16 \%$, $36.19 \%$, and $19.64 \%$ for the individuals (density) with DBH between $2-10 \mathrm{~cm}, 10-20 \mathrm{~cm}$ and $>20 \mathrm{~cm}$, respectively. The large proportions of small-sized tree/shrub individuals suggest that the forest vegetation has good reproduction potential. Similar reports were made by Didita [82]; Enkossa [67] and Abdena [45]; which in turn suggests that it is a 
TABLE 2: Density distribution of four dominant tree species in the Kenech forest.

\begin{tabular}{lccc}
\hline SN & Species & No of matured species & Density \\
\hline 1 & Prunus africana & 98 & 61.25 \\
2 & Ekebergia capensis & 157 & 98.13 \\
3 & Galinera saxifraga & 90 & 56.25 \\
4 & Croton macrostachytus & 222 & 138.75 \\
\hline
\end{tabular}

TABLE 3: Comparisons of tree densities with DBH between 10 and 20 (a) and tree density with DBH $>20 \mathrm{~cm}$, (b) from Kenech forest with 10 other forests in Ethiopia.

\begin{tabular}{|c|c|c|c|c|}
\hline Forest & Density DBH $10-20 \mathrm{~cm}$ (a) & Density DBH > $20 \mathrm{~cm}(\mathrm{~b})$ & Ratio & Sources \\
\hline Masha Anderacha & 385.7 & 160.5 & 2.4 & {$[63]$} \\
\hline Bibita & 500.5 & 265.6 & 1.88 & {$[64]$} \\
\hline Dodola & 521 & 351 & 1.48 & [51] \\
\hline Menna Angetu & 292 & 139 & 2.1 & {$[65]$} \\
\hline Jima & 335 & 184 & 1.8 & {$[66]$} \\
\hline Alata-Bolale & 365 & 219 & 1.67 & {$[67]$} \\
\hline Komto & 330 & 215 & 1.53 & {$[68]$} \\
\hline Chato & 333 & 194 & 1.71 & {$[45]$} \\
\hline Jibat & 124.7 & 220.6 & 0.56 & [69] \\
\hline Belete & 305.7 & 149 & 2.04 & [53] \\
\hline Kimphe Lafa & 183.9 & 135.3 & 1.36 & {$[70]$} \\
\hline Berbere & 214.6 & 140.6 & 1.56 & {$[33]$} \\
\hline Asabot & 137.5 & 71.16 & 1.93 & [71] \\
\hline Yegof & 338.75 & 82.5 & 4.1 & [72] \\
\hline Kenech & 304 & 165 & 1.8 & Present study \\
\hline
\end{tabular}

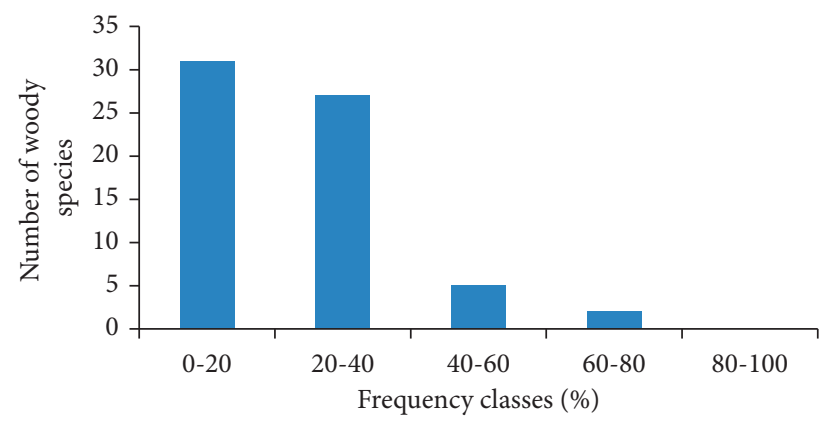

FIGURE 3: Frequency class distributions of woody species in Kenech forest.

healthy forest with active regeneration and recruitment of new individuals $[28,83]$. This type of population structure is reported by other researchers such as Senbeta and Teketay [9]; Abdena [45]; Sarkar and Devi [84]; Bogale et al. [33]; and Siraj and Zhang [25]. However, this pattern of population structure does not depict the general patterns of population dynamics and recruitment processes of a given individual species of a forest.

From the population dynamics point of view, the examination of patterns of species population structure could provide valuable information about their regeneration and/ or recruitment status as well as viability status of the population that could further be employed for devising evidence-based conservation and management strategies [85]. Analysis of population structures for each individual woody species could provide more realistic and typical information for forest conservation and management activities $[16,60,77,84,86]$.
The frequency distribution of $\mathrm{DBH}$ classes of some selected important woody species in the study area showed different types of population structures (Figures 5(a)-5(f)). Similarly, various patterns of species population structures have been reported for different species forests of the country $[25,45,87]$.

In the Kenech natural forest, the evaluation of selected tree species reveals different patterns of population structure. The first pattern of population structure showed an inverted J shape (L shape) (Figure 5(a)), which shows a pattern where species frequency distribution has the highest frequency in the lower diameter classes and gradual decrease towards the higher classes which shows good reproduction and requirement. This pattern was exemplified by Ekebergia capensis, Prunus africana, Albizia gummifera, Vepris dainelli, Rothmannia urcelliformis, Croton macrostachyus, and Galiniera saxifraga. Besides, this pattern suggests a good reproduction and recruitment capacity. 


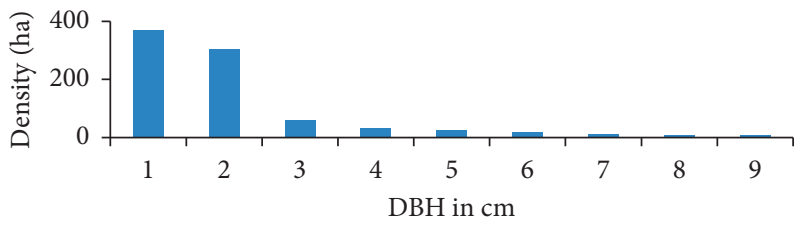

Figure 4: Size class distribution of stem density across diameter classes in Kenech forest.

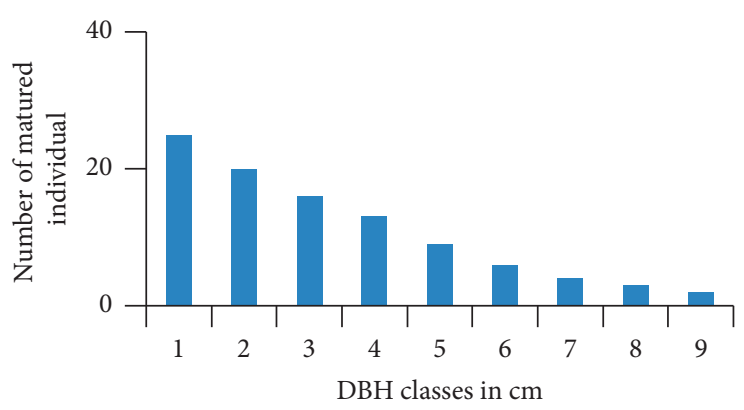

(a)

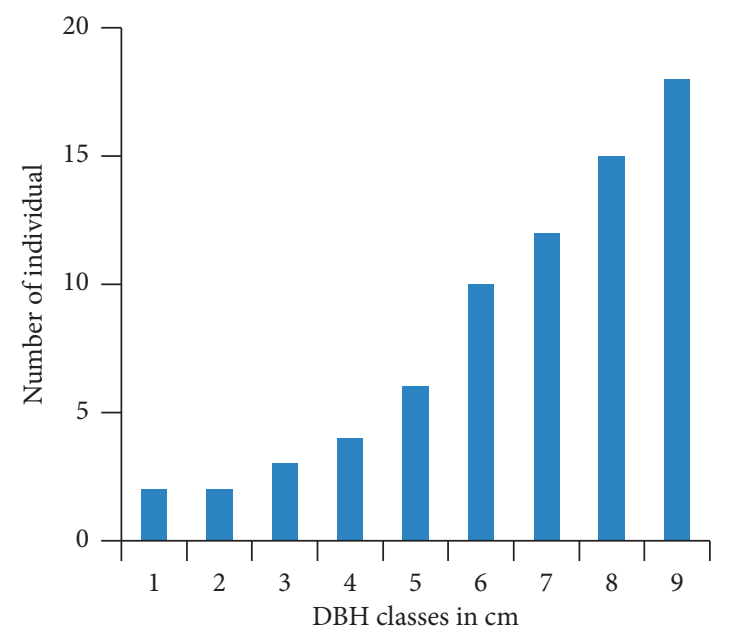

(c)

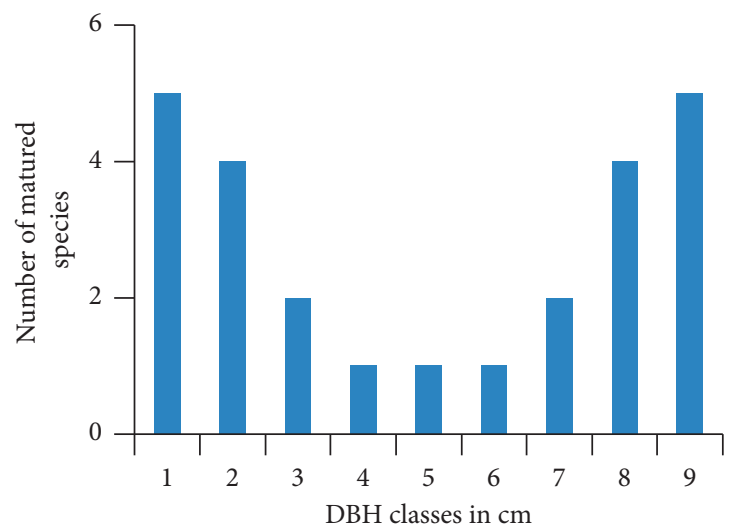

(e)

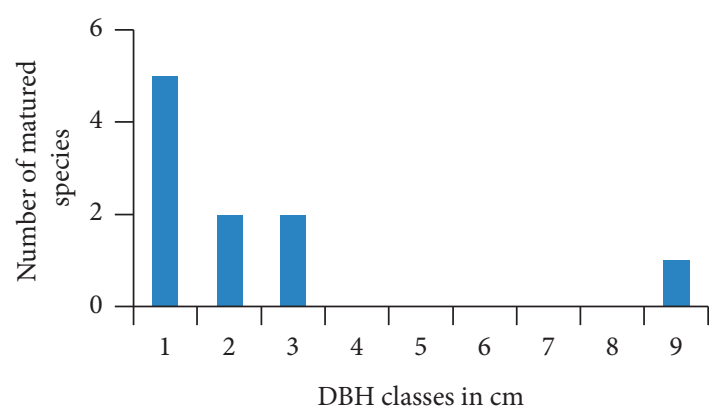

(b)

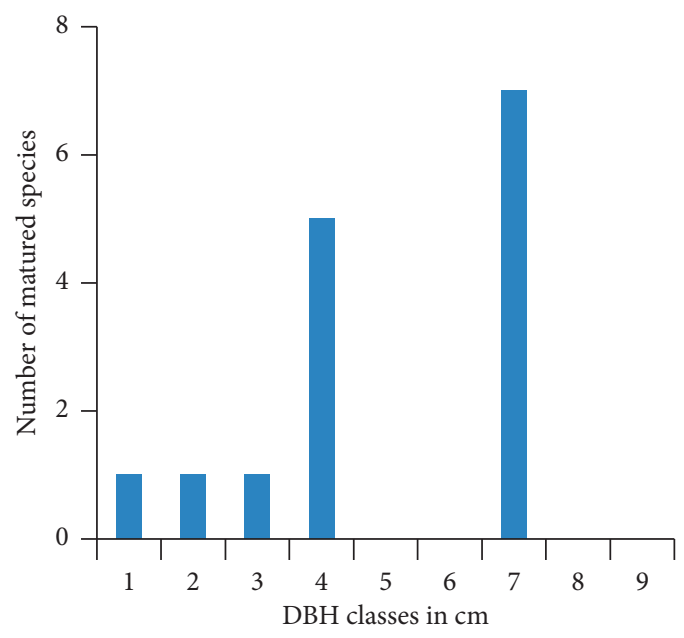

(d)

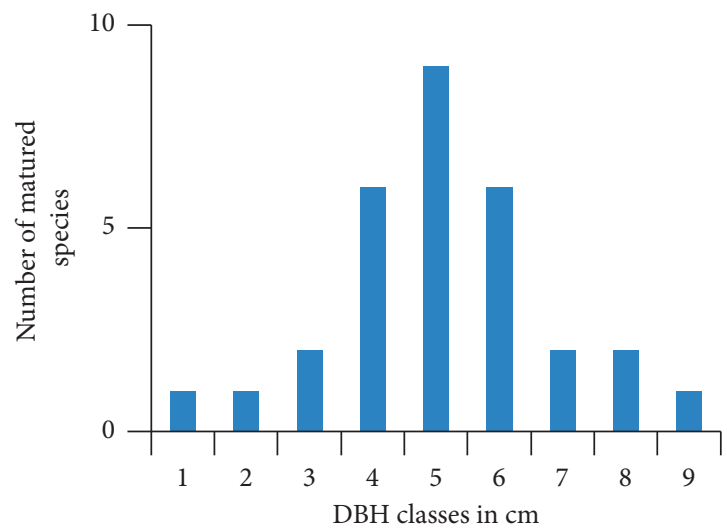

(f)

Figure 5: (a-f) Six representative patterns of population structure of the Kenech natural forest. 
The second pattern of the population structure showed broken inverted J shape in which the density of in the lower $\mathrm{DBH}$ class is very high but becoming lower in the highest $\mathrm{DBH}$ classes even nothing in some $\mathrm{DBH}$ classes (Figure 5(b)). This showed that there is a selective cutting of the species for different purposes like for construction and fuel wood. The species in $\mathrm{DBH}$ classes 1 and 2 are high in number, but the species in DBH classes $4-8$ is absent. This could be attributed to selective removal of individuals of the preferred size of this species for the purpose of logging and constructions. This pattern exemplifies Cordia africana, Combretum collinum, and Dracaena afromontana.

The third pattern exemplifies J shape which shows a type of frequency distribution in which there is a low number of individuals in the lower diameter classes but increases towards the higher classes. Some of the species such as Ehretia cymosa, Gardenia ternifolia, Celtis africana, and Podocarpus falcatus have a J-shape pattern of population structure (Figure 5(c)). This pattern showed the presence of very few numbers of individuals in the lower DBH classes. It is to be noted that these species are not highly exploited by the local people community for various uses, and there is no selective logging of them. This could account for the presence of the upper $\mathrm{DBH}$ class of these species of the Kenech natural forest. In this case, there are many individuals in the upper $\mathrm{DBH}$ classes. The regeneration status of these plant species is poor due to the presence of the lower number of plant species at the lower DBH classes.

The fourth pattern of population structure shows irregular in which they are distributed differently in almost all classes (Figure 5(d)), and the first pattern was formed by the species having a high number of individuals in the fourth and seventh $\mathrm{DBH}$ classes and then decrease with increasing $\mathrm{DBH}$ towards the higher classes. Species included in this pattern of population structure were Acacia abyssinica and Diospyros abyssinica.

The fifth pattern of species population showed $U$ shape (Figure 5(e)) which shows a type of frequency distribution in which there is a high number of lowest and highest diameter classes but a relatively low number in the intermediate diameter classes in which the intermediate diameter classes are less represented may be due to selective removal of medium sized individuals. The species in the first DBH classes were high followed by a decline in the middle and then rise again at larger size classes. The two plant species which exhibited good reproduction and poor recruitment in study area were Psychotria orophila and Chionanthus mildbraediare. The pattern of population structure illustrated by Psychotria orophila could be termed as U-shaped. In this species, DBH classes of the $3 \mathrm{rd}, 4^{\text {th }}$, and 5 th are decreased in number.

The sixth population structure pattern showed a bell shape (Figure 5(f)) in which the number of individuals in the middle diameter classes is high and low in lower and higher diameter classes. According to Senbeta [76], bell-shape pattern indicates a poor reproduction and recruitment of species which may be associated with intense competition from surrounding trees. The pattern of population structure illustrated by Rytigynia neglecta could be termed as bellshaped.
3.2.4. Basal Area and Dominance and Importance Value (IVI) of Woody Species. Basal area is used to elucidate the crowdedness of a stand of natural vegetation. The total basal area calculated for the study area was about $56.8 \mathrm{~m}^{2} /$ ha for woody plants $>2 \mathrm{~cm}$ in $\mathrm{DBH}$. This is further partitioned into $3.4 \mathrm{~m}^{2} /$ ha for individuals with $\mathrm{DBH}$ between 2 and $10 \mathrm{~cm}$ (small-sized), $5.2 \mathrm{~m}^{2} /$ ha for $\mathrm{DBH}$ between 10 and $20 \mathrm{~cm}$ (medium-sized), and $48.2 \mathrm{~m}^{2} /$ ha for $\mathrm{DBH}>20 \mathrm{~cm}$ (largesized). The highest percentage of the basal area $(38.73 \%)$ is contributed by $\mathrm{DBH}$ class $7(\mathrm{DBH}>60.0 \mathrm{~cm})$. There is a considerable decrease in the number of individuals with increasing DBH size and basal area. Individuals that attained higher DBH classes are fewer in number and contributed over $70 \%$ to the total basal area.

Noteworthy is that a basal area of $42.2 \mathrm{~m}^{2} /$ ha was accounted for by five important tree species, i.e., Ekebergia capensis $\left(10.4 \mathrm{~m}^{2} / \mathrm{ha}\right)$, Prunus africana $\left(12.5 \mathrm{~m}^{2} / \mathrm{ha}\right)$, Galinera saxifraga $\left(6.8 \mathrm{~m}^{2} / \mathrm{ha}\right)$, Celtis africana $\left(5.6 \mathrm{~m}^{2} / \mathrm{ha}\right)$, and Croton macrostachytus $\left(6.9 \mathrm{~m}^{2} / \mathrm{ha}\right)$ (Table 4$)$.

The relative importance of tree species in a forest can better be depicted from measurements of the basal area than stem counts [87]. Therefore, species with the largest contribution in the basal area can be considered the most important woody species in the forest. Accordingly, the most dominant species of the Kenech natural forest are presented in (Table 5).

The IVI values are playing a key role to understand the ecological significance of the tree species in community structure $[92,93]$. The floristic structure was studied by using an index namely, importance value index, derived following Curtis and McIntosh's [94]. This index is generally calculated as the sum of the RD, RF, and RDO for each woody species. The relative ecological importance of the forest is expressed by IVI. High SIV is attributed to their high basal area, high relative frequency and high relative density. The greatest SIV reflects the degree of dominancy and abundance of a given species in relation to the other species in the area. It is also used for setting priority/ranking species management and conservation practices and helps to identify their sociological status (structure) in a certain plant community as dominant or rare species [49].

In the current study, high IVI was obtained for seven tree species. These species are, in the descending order of IVI, Podocarpus falcatus, Pouteria adolf-friederici, Mimusops kummel, Celtis africana, Ochna holstii, Diospyros abysinica, and Albizia gummifera (Table 6). These dominant species accounted for over $45 \%$ of the total SIV of the Kenech natural forest. On the other hand, six species had less than 2\% IVI values. Examples are, in descending order of SIV, Cordia africana, Dracaena steudneri, Maesa lanceolata, Ficus sur, Polyscias fulva, and Ekebergia capensis. Such low abundance may be due to either adverse environmental conditions or random distribution of available resources in the forest [95] exhibited very low frequency in the Kenech natural forest. In the case of the former, it was so because illegal logging by local people has increased from time to time for their daily income. A similar observation was reported by Bekele [96], while the latter was determined by altitudinal ranges of the forest. Olea welwitschii and Ficus sur 
TABLE 4: Basal area and density distribution of four dominant tree species in the Kenech forest.

\begin{tabular}{lcc}
\hline Species & Basal area $\left(\mathrm{m}^{2} / \mathrm{ha}\right)$ & $\%$ \\
\hline Prunus africana & 12.5 & 22.01 \\
Ekebergia capensis & 10.4 & 18.31 \\
Galinera saxifraga & 6.8 & 11.97 \\
Croton macrostachytus & 6.9 & 12.15 \\
Celtis africana & 5.6 & 9.86 \\
\hline
\end{tabular}

TABLE 5: Basal area of some of selected forests in Ethiopia.

\begin{tabular}{lcc}
\hline Forest & BA m ${ }^{2} /$ ha & Authors \\
\hline Berbere & 87.49 & {$[33]$} \\
Jibat & 60.9 & {$[69]$} \\
Central plateau of Shewa Wof-washa & 101.8 & {$[87]$} \\
Central plateau of ShewaMenegesha & 36.5 & {$[87]$} \\
Central plateau of Shewa chilimo & 36.1 & {$[87]$} \\
Denkoro & 45 & {$[50]$} \\
Gedo & 35.45 & {$[88]$} \\
Chato & 65.8 & {$[45]$} \\
Komto & 50.72 & {$[68]$} \\
Dodola & 129 & {$[51]$} \\
Menna Angetu & 94 & {$[65]$} \\
Belete & 103.5 & {$[53]$} \\
Kimphe Lafa & 114.4 & {$[70]$} \\
Alata-Bolale & 53.3 & {$[67]$} \\
Asabot & 22.45 & {$[71]$} \\
Angada & 79.8 & {$[89]$} \\
Yemrehane Kirstos & 72 & {$[90]$} \\
Gura Lopho & 29.63 & \\
Adelle & 26 & \\
Kafta Sheraro national park & {$[91]$} \\
Kenech & $79.3 \mathrm{~m}^{2} \cdot \mathrm{ha}^{-1}$ & \\
\hline
\end{tabular}

which are typical species of the moist montane forest were less frequent in the Kenech natural forest (Table 6), which could be attributed to altitudinal, edaphic, and topographic factors or other ecological reasons. In terms of conservation, species with low IVI require high conservation approaches and thus should be prioritized for conservation.

3.2.5. Family Importance Value (FIV). Woody species FIV value was calculated from relative density, relative diversity, and relative dominance. At the family level, as for the species, the stem density, relative basal area, and FIV were analyzed to assess species-rich family/dominant family in all sampled areas of the forest. In view of this, this forest is dominated by Sapotaceae, $19.5 \mathrm{~m}^{2} /$ ha $(30 \%$ of the total basal area), followed by Podocarpaceae, $12.9 \mathrm{~m}^{2} /$ ha $(19.9 \%)$, Ulmaceae, $7.7 \mathrm{~m}^{2} / \mathrm{ha}(11.9 \%)$, and Fabaceae, $5.65 \mathrm{~m}^{2} / \mathrm{ha}$ (8.7\%).

The most dominant families/species are also those which have the highest IVI [94]. This was true with the present study where the dominant families include Sapotaceae $(\mathrm{FIV}=51.1), \quad$ Podocarpaceae $\quad(\mathrm{FIV}=30.80), \quad$ Fabaceae $(\mathrm{FIV}=23.49)$, and Ulmaceae $(\mathrm{FIV}=20.41)$, and these four families are distinctly dominant in terms of FIV and together contributing more than $70 \%$ of the total basal area. The reason for their dominance could be they might have developed strategies such as resistance, reproductive mechanisms, and conductivity, ecological, and morphological adaptations which helped them to survive in the area.

The present study showed that eight families contributed about $75.8 \%$ to the total FIV. Sapotaceae and Podocarpaceae are the most dominant families in the Kenech natural forest with $51.11 \%$ and $30.86 \%$ FIV, respectively. Families such as Fabaceae (23.49\%), Oleaceae (22.72\%), Rubiaceae (21.40\%), Oleaceae (21.10\%), and Ulmaceae (20.41) have also exhibited relatively higher FIV compared to the remaining families of plants inhabiting the Kenech natural forest.

3.2.6. Regeneration Status of Kenech Natural Forest. The composition, distribution and density of seedlings and saplings indicate the future status of the forest. Accordingly, from the 80 representative woody species, a total of 42 species $(64.61 \%)$ were represented by both seedling and sapling class, whereas eight species represented only by seedling and six species represented by sapling alone. Other 9 species (13.84\%) were not represented in both seedling and sapling class (Figure 6).

The total seedling, sapling, and mature woody species densities of 80 selected woody species were about 770.6 (32.7\%) ha $\mathrm{ha}^{-1}, 748.2$ (31.7\%) ha $\mathrm{ha}^{-1}$, and 840 (35.6\%) ha individuals per hectare, respectively (Figure 7 ). The domination of small-sized individual species in the forest was available that is the quality of normal rate of regeneration. 
TABLE 6: The IVI of woody species in the sampled area with corresponding values for each species.

\begin{tabular}{|c|c|c|c|c|}
\hline Species & RF (\%) & $\mathrm{RD}(\%)$ & RDO (\%) & SIV (\%) \\
\hline Cordia africana & 0.50 & 0.57 & 0.28 & 1.35 \\
\hline Dracaena steudneri & 0.5 & 0.31 & 0.63 & 1.44 \\
\hline Ficus sur & 0.50 & 0.31 & 0.74 & 1.55 \\
\hline Ekebergia capensis & 1.00 & 0.63 & 0.26 & 1.89 \\
\hline Syzygium guineensis & 0.75 & 0.57 & 1.25 & 2.57 \\
\hline Prunus africana & 0.75 & 1.14 & 0.86 & 2.75 \\
\hline Chionanthus mildbraedii & 2.76 & 1.40 & 0.24 & 4.40 \\
\hline Rytigynia neglecta & 2.51 & 1.46 & 0.81 & 4.78 \\
\hline Clausena anistata & 3.01 & 2.42 & 0.57 & 6.00 \\
\hline Croton macrostachyus & 1.00 & 2.10 & 3.2 & 6.3 \\
\hline Olea welwitschii & 2.51 & 1.65 & 3.02 & 7.18 \\
\hline Rothmonnia urcelliformi & 3.76 & 3.06 & 0.54 & 7.36 \\
\hline Psychotria orophila & 3.26 & 4.59 & 0.94 & 8.79 \\
\hline Teclea nobilis & 4.52 & 3.5 & 0.99 & 9.01 \\
\hline Olea capensis subsp. Macrocarpa & 3.0 & 5.29 & 1.18 & 9.47 \\
\hline Carissa spinarum & 3.01 & 6.37 & 1.07 & 10.45 \\
\hline Albizia gummifera & 3.76 & 357 & 7.4 & 14.08 \\
\hline Diospyros abyssinica & 3.51 & 5.10 & 7.04 & 15.65 \\
\hline Ochna holstii & 2.76 & 16.58 & .37 & 19.71 \\
\hline Celtis Africana & 4.27 & 4.97 & 11.79 & 21.03 \\
\hline Mimusops kummel & 5.77 & 8.86 & 9.09 & 23.72 \\
\hline Pouteria adolfi-friederici & 3.01 & 4.97 & 20.57 & 28.55 \\
\hline Podocarpus falcatus & 6.03 & 7.33 & 19.63 & 32.99 \\
\hline Others & 25.00 & 6.59 & 0.86 & 32.47 \\
\hline Total & 100.00 & 100.00 & 100.00 & 300.00 \\
\hline
\end{tabular}

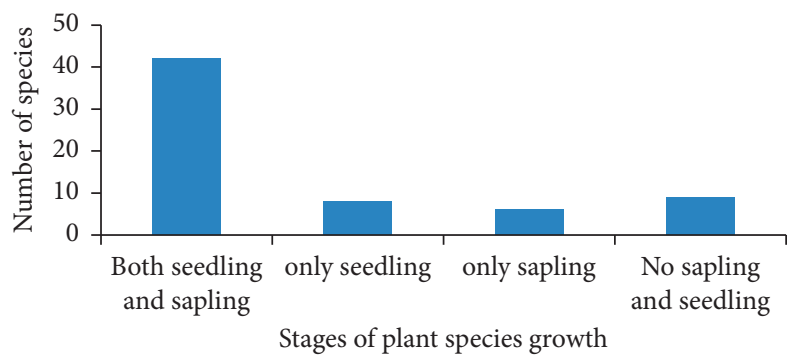

FIgURE 6: The number of plant species with seedling, sapling, and matured species.

However, fair regeneration was experienced in the study site because of the composition, distribution, and density of seedlings and saplings less than matured individual species.

The ratio of mature species to seedlings was 1.1; mature species to saplings was 1.13; and seedlings to saplings were 1.03. These show that the distribution of matured woody plant species as a whole is greater than that of seedlings and saplings. Based on the results of this study, 9 species (13.84\%) of the total were not represented by both seedling and sapling stages. These species were Cordia africana, Dracaena steudneri, Euphorbia ampliphyla, Ficus vasta, Rothmania urceliformis, Olea capensis subsp. macrocarpa, Ficus sur, Podocarpus falcatus, and Pouteria adolfi-friedericii.

The possible reasons for absence or insufficient seedling and sapling for the woody species in the forest could be grazing and browsing, seed predation, lack of safe site for seed recruitment, nature of seeds of certain trees which seek dormancy period, litter accumulation, pathogens, species specificity, and moisture stress or probably they might have other alternative adaptations for propagation and reproduction rather than seed germination. Similar findings were also reported by Denu [64]; Shibru and Balcha [97]; and Gemechu [98]. This may suggest that these species are either under threat of local extinction or may prefer coppices or sprouts as the strategy of survival. Thus, this situation calls for conservation measures through prioritization. To ensure this, the woody species of the Kenech natural forest were grouped into three priority classes on the basis of their seedling and sapling densities following Gurmessa et al. [68]. These are class 1 -those species with no seedlings and saplings, class 2-those with seedlings but no saplings, and class 3 -those with both seedlings and saplings $\geq 1$ individual/ha (Figure 8 ).

Woody plant species with good regeneration status in Kenech forest were Acanthus eminens, Maytenus arbutifolia, Coffee arabica, Erythrococca trichogyne, Acacia abyssinica, Millettia ferruginea, Syzygium guineense, and Olea welwitschii. 


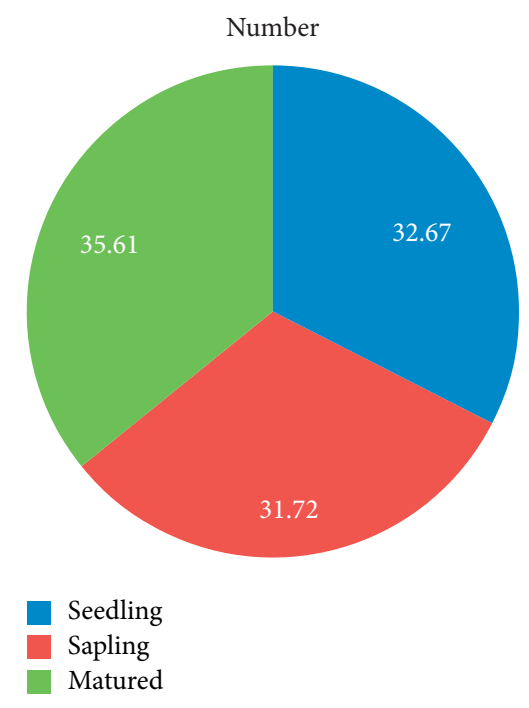

FIGURE 7: Density distribution percentage of seedling, sapling, and matured woody plant species in Kenech forest.

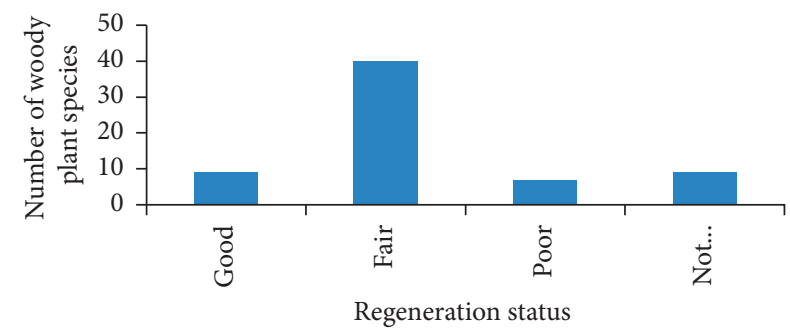

FIGURE 8: The regeneration status of woody plant species in Kenech forest.

\section{Conclusions and Recommendations}

4.1. Conclusion. Plant species are the potential stock for future genetic resources and would have great implications for the environment, biological diversity, and socio-economic importance. In this study, useful information on the present condition of the woody species diversity, structure, and regeneration status of the Kenech forest was obtained, which can be used as baseline information on ecological and botanical studies. The analysis of overall population structure of the most common species indicated that the majority of them showed a reversed J shape which indicates stable population structures. Regeneration analysis of woody species revealed that most of tree species are with seedling and sapling stage in the forest, some tree species are without sapling stage, while others are represented by all stages (seedling, sapling, and mature).

4.2. Recommendations. The inclusion of local communities in the forest conservation activities and management is the only realistic option to reduce the forest loss and its various resources as complex and valuable natural resource system. The result of this study can contribute towards the understanding of the woody plant species diversity, population structure, and regeneration status of the forest of the south western part of the country which is of considerable importance in its conservation.

To conserve the biodiversity of the area, detailed ecological and botanical studies are vital concerning the species composition, diversity, and distribution of plant species in relation to the environmental factors such as soil type and properties. The present study is limited to woody species composition and structure, then further studies on environmental parameters, forest management, and conservation system, and soil seedbank, and regeneration of the woody species is recommended. The future management strategy of the Kenech natural forest should focus on multiple-use conservation approaches.

\section{Data Availability}

Data will be available upon request.

\section{Conflicts of Interest}

The authors declare that they have no conflicts of interest.

\section{References}

[1] Z. Woldu, S. Edward, A. Demissie, T. Bekele, and G. Haase, "Forests in the vegetation types of ethiopia and their status in the geographical context," Forest Genetic Resource Conservation: Principles, Strategies and Actions, Institute of Biodiversity Conservation and Research, Addis Ababa, Ethiopia, 1999.

[2] E. Kelbessa, T. Bekele, A. Gebrehiwot, and G. Hadera, "A socioeconomic case study of the bamboo sector in Ethiopia. An analysis of the production-to-consumption system," International Network for Bamboo and Rattan Working Paper, vol. 25, 2000.

[3] D. M. Olson and E. Dinerstein, "The global 200: priority ecoregions for global conservation," Annals of the Missouri Botanical Garden, vol. 89, no. 2, p. 199, 2002.

[4] E. Kelbessa and S. Demissew, "Diversity of vascular plant taxa of the flora of Ethiopia and Eritrea," Ethiopian Journal of Biological Sciences, vol. 13, 2014.

[5] M. Siraj, K. Zhang, D. Sebsebe, and W. Zerihun, "Floristic composition and plant community types in Maze national park, southwest Ethiopia," Applied Ecology and Environmental Research, vol. 15, no. 1, pp. 245-262, 2017.

[6] S. Demissew, O. E Stabbetorp, and I. Nordal, Flowers of Ethiopia and Eritrea Aloes and Other Lilies, Master Printing Press, Addis Ababa, Ethiopia, 2003.

[7] W. Gebremarkos, "The forest resources of Ethiopia. Past and present," Walia, vol. 19, pp. 10-28, 1998.

[8] Z. Asfaw and M. Tadesse, "Prospects for sustainable use and development of wild food plants in Ethiopia," Economic Botany, vol. 55, no. 1, pp. 47-62, 2001.

[9] F. Senbeta and D. Teketay, "Diversity, community types and population structure of woody plants in Kimphee forest, a unique nature reserve in southern Ethiopia," Ethiopian Journal of Biological Sciences, vol. 2, no. 2, pp. 169-187, 2003.

[10] D. Debebe, "The Impact of deforestation on soil erosion and climate change: structural equations modeling," Doctoral dissertation, Addis Ababa University, Addis Ababa, Ethiopia, 2010.

[11] K. Hundera and B. Deboch, "Woody species composition and structure of the Gurra Farda forest, snnpr, south wastern 
Ethiopia," Ethiopian Journal of Education and Sciences, vol. 3, no. 2, 2008.

[12] M. Siraj, K. Zhang, W. Xiao et al., "Does participatory forest management save the remnant forest in Ethiopia?" Proceedings of the National Academy of Sciences, India Section B: Biological Sciences, vol. 88, no. 1, pp. 1-14, 2016.

[13] S. Rosell, M. Olvmo, and B. Holmer, "Cultivated land-a scarce commodity in a densely populated rural area in South Wollo, Ethiopia," Journal of Land Use Science, vol. 12, no. 4, pp. 252-270, 2017.

[14] K. T. Deribew and D. W. Dalacho, "Land use and forest cover dynamics in the North-eastern Addis Ababa, central highlands of Ethiopia," Environmental Systems Research, vol. 8, no. 1, p. 8, 2019.

[15] M. Siraj, K. Zhang, and K. Moges, "Retrospective analysis of land use land cover dynamics using GIS and remote sensing in central highlands of Ethiopia," Journal of Landscape Ecology, vol. 11, no. 2, pp. 31-52, 2018.

[16] E. Kelbessa and T. Soromessa, "Interfaces of regeneration, structure, diversity and uses of some plant species in Bonga forest: a reservoir for wild coffee gene pool," SINET: Ethiopian Journal of Science, vol. 31, no. 2, pp. 121-134, 2008.

[17] L. Mulugeta and W. Tadesse, "Review of forest woodland and bushland resources in Ethiopia up to 2008," in Ethiopian Environment Review, No. 1, E. Sue, Ed., pp. 131-186, Addis Ababa, Forum for Environment, Addis Ababa, Ethiopia, 2010.

[18] T. Soromessa, D. Teketay, and S. Demissew, "Ecological study of the vegetation in Gamo Gofa zone, southern Ethiopia," Tropical Ecology, vol. 45, no. 2, pp. 209-222, 2004.

[19] K. Yeshitela and T. Bekele, "Plant community analysis and ecology of Afromontane and transitional rainforest vegetation of southwestern Ethiopia," SINET: Ethiopian Journal of Science, vol. 25, no. 2, pp. 155-175, 2002.

[20] M. Reusing, "Change detection in natural high forests of Ethiopia using remote sensing and GIS techniques," IAPR, vol. 33, pp. 1253-1258, 2000.

[21] G. Gebeyehu, T. Soromessa, T. Bekele, and D. Teketay, "Species composition, stand structure, and regeneration status of tree species in dry Afromontane forests of Awi zone, northwestern Ethiopia," Ecosystem Health and Sustainability, vol. 5, 2019.

[22] A. Paul, M. L. Khan, and A. K. Das, "Population structure and regeneration status of rhododendrons in temperate mixed broad-leaved forests of western Arunachal Pradesh, India," Geology, Ecology, and Landscapes, vol. 3, no. 3, pp. 168-186, 2019.

[23] G. Eilu and J. Obua, "Tree condition and natural regeneration in disturbed sites of Bwindi impenetrable forest national park, southwestern Uganda," Tropical Ecology, vol. 46, no. 1, pp. 99-112, 2005.

[24] K. Henle, K. F. Davies, M. Kleyer, C. Margules, and J. Settele, "Predictors of species sensitivity to fragmentation," Biodiversity and Conservation, vol. 13, no. 1, pp. 207-251, 2004.

[25] M. Siraj and K. Zhang, "Structure and natural regeneration of woody species at central highlands of Ethiopia," Journal of Ecology and the Natural Environment, vol. 10, no. 7, pp. 147-158, 2018.

[26] P. Segawa and D. N. Nkuutu, "Diversity of vascular plants on ssese islands in lake Victoria, central Uganda," African Journal of Ecology, vol. 44, no. 1, pp. 22-29, 2006.

[27] G. Dutta and A. Devi, "Plant diversity, population structure, and regeneration status in disturbed tropical forests in Assam, northeast India," Journal of Forestry Research, vol. 24, no. 4, pp. 715-720, 2013.
[28] J. O. Maua, H. MugatsiaTsingalia, J. Cheboiwo, and D. Odee, "Population structure and regeneration status of woody species in a remnant tropical forest: a case study of south Nandi forest, Kenya," Global Ecology and Conservation, vol. 21, Article ID e00820, 2020.

[29] N. Arya and J. Ram, "Forest disturbance and its impact on species richness and regeneration of Uttarakhand Himalaya," NY Science Journal, vol. 4, no. 6, pp. 21-27, 2011.

[30] M. Dhaulkhandi, A. Dobhal, S. Bhatt, and M. Kumar, "Community structure and regeneration potential of natural forest site in Gangotri, India," Journal of Basic and Applied Sciences, vol. 4, no. 1, pp. 49-52, 2008.

[31] N. F. Good and R. E. Good, "Population dynamics of tree seedlings and saplings in a mature eastern hardwood forest," Bulletin of the Torrey Botanical Club, vol. 99, no. 4, pp. 172-178, 1972.

[32] A. Assefa, S. Demissew, and Z. Woldu, "Floristic composition, structure and regeneration status of Masha forest, south-west Ethiopia," African Journal of Ecology, vol. 52, no. 2, pp. 151-162, 2014.

[33] T. Bogale, D. Datiko, and S. Belachew, "Structure and natural regeneration status of woody plants of Berbere afromontane moist forest, Bale zone, south east Ethiopia; implication to biodiversity conservation," Open Journal of Forestry, vol. 7, no. 3, p. 352, 2017.

[34] H. Getaneh and A. Seid, "Floristic composition, structure and regeneration status of Achera natural forest in Chilga district, northwest Ethiopia," Ethiopian Journal of Biological Sciences, vol. 14, no. 2, pp. 217-231, 2015.

[35] B. W. Meshesha, B. A. Tsegay, and B. B. Telake, "Survey on composition of perennial vegetation in sesa mariam monastery, northwestern Ethiopia," BMC Research Notes, vol. 8, no. 1, p. 622, 2015.

[36] S. Tegegne and B. Workineh, "Vegetative structure, floristic composition and natural regeneration of a species in Ylat forest, Meket Woreda, northeastern Ethiopia," Asian Journal of Forestry, vol. 1, no. 1, pp. 40-53, 2017.

[37] F. Temesgen and B. Warkineh, "Woody species structure and regeneration status in Kafta Sheraro national park dry forest, Tigray region, Ethiopia," International Journal of Forestry Research, vol. 2020, Article ID 4597456, 22 pages, 2020.

[38] EFAP, Ethiopian Forestry Action Program, Volume III. The Challenge for Development, Ministry of Natural Resources, Addis Ababa, Ethiopia, 1994.

[39] EMSA, Rainfall and Temperature Data for Chena District, Ethiopiaian Meteorological Services Agency, Addis Ababa, Ethiopia, 2009.

[40] CWRDO, Chena Woreda Rural Development Office Socioeconomic Profile of Chena District, CWRDO, Wacha, Ethiopia, 2018.

[41] P. Mohr, The Geology of Ethiopia, HIS University Press, Addis Ababa, Ethiopia, 1971.

[42] I. B. Friis, "Forest and forest trees of northeast tropical Africa: their natural habitats and distribution pattern in Ethiopia, Djibouti and Somalia," Kew Bulletin Additional Series, vol. 15, p. 396, 1992.

[43] M. Abebe, Nature and Management of Ethiopian Soils, Alamaya University of Agriculture, Dire Dawa, Ethiopia, 1997.

[44] CSA, The 2007 Population and Housing Census of Ethiopia Result for SNNPR, CSA, Addis Ababa, Ethiopia, 2007.

[45] F. Abdena, "Floristic composition and structure of vegetation of Chato natural forest in Horo Guduru Wollega zone, Oromia national regional state, west Ethiopia," Doctoral 
dissertation, Addis Ababa University, Addis Ababa, Ethiopia, 2010.

[46] NBSAP, National Biodiversity and Action Plan, IBC, Addis Ababa, Ethiopia, 2005.

[47] F. Senbeta and M. Denich, "Effects of wild coffee management on species diversity in the Afromontane rainforests of Ethiopia," Forest Ecology and Management, vol. 232, no. 1-3, pp. 68-74, 2006.

[48] M. Kent, Vegetation Description and Data Analysis: A Practical Approach, John Wiley \& Sons, Hoboken, NJ, USA, 2011.

[49] M. Kent and P. Coker, Vegetation Description and Analysis. A Practical Approach, John Wiley and Sons, New York, NY, USA, 1992.

[50] A. Ayalew, T. Bekele, and S. Demissew, "The undifferentiated afromontane forest of Denkoro in the central highland of Ethiopia: a floristic and structural analysis," SINET: Ethiopian Journal of Science, vol. 29, no. 1, pp. 45-56, 2006.

[51] K. Hundera, T. Bekele, and E. Kelbessa, "Floristics and phytogeographic synopsis of a dry afromontane coniferous forest in the Bale mountains (Ethiopia): implications to biodiversity conservation," SINET: Ethiopian Journal of Science, vol. 30, no. 1, pp. 1-12, 2007.

[52] M. Kuma and S. Shibru, "Floristic composition, vegetation structure, and regeneration status of woody plant species of Oda forest of Humbo carbon project, Wolaita, Ethiopia," Journal of Botany, vol. 2015, Article ID 963816, 9 pages, 2015.

[53] K. Gebrehiwot and K. Hundera, "Species composition, plant community structure and natural regeneration status of Belete moist evergreen Montane forest, Oromia regional state, southwestern Ethiopia," Momona Ethiopian Journal of Science, vol. 6, no. 1, pp. 97-101, 2014.

[54] U. Shankar, "A case of high tree diversity Ina Sal (shorea robusta)-dominated lowland forest of eastern himalaya: floristic composition, regeneration and conservation," Current Science, vol. 81, pp. 776-786, 2001.

[55] K. P. G. Tiwari, K. Tadele, F. Aramde, and S. C. Tiwari, "Community structure and regeneration potential of shorea robusta forest in subtropical submontane zone of Garhwal Himalaya, India," Nature and Science, vol. 8, pp. 70-74, 2010.

[56] D. S. Kacholi, "Edge-interior disparities in tree species and structural composition of the Kilengwe forest in Morogoro region, Tanzania," ISRN Biodiversity, vol. 2014, Article ID 873174, 8 pages, 2014.

[57] G. Fisaha, K. Hundera, and G. Dalle, "Woody plants' diversity, structural analysis and regeneration status of Wof Washa natural forest, north-east Ethiopia," African Journal of Ecology, vol. 51, no. 4, pp. 599-608, 2013.

[58] A. Belayneh, T. Bekele, and S. Demissew, "The natural vegetation of Babile elephant sanctuary, eastern Ethiopia: implications for biodiversity conservation," Ethiopian Journal of Biological Sciences, vol. 10, no. 2, pp. 137-152, 2011.

[59] S. Shimelse, T. Bekele, and A. Mengistu, "Floristic diversity and structure of Nechisar national park, Ethiopia," Journal of the Drylands, vol. 3, no. 1, pp. 165-180, 2010.

[60] A. Dibaba, T. Soromessa, E. Kelbessa, and A. Tilahun, "Diversity, structure and regeneration status of the woodland and riverine vegetation of sire beggo in Gololcha district, eastern Ethiopia," Momona Ethiopian Journal of Science, vol. 6, no. 1, pp. 70-96, 2014.

[61] H. Zegeye, D. Teketay, and E. Kelbessa, "Diversity and regeneration status of woody species in Tara Gedam and Abebaye forests, northwestern Ethiopia," Journal of Forestry Research, vol. 22, no. 3, pp. 315-328, 2011.
[62] P. J. Grubb, J. R Lloyd, T. D. Pennington, and T. C. Whitmore, "A comparison of montane and lowland rain forest in Ecuador I. The forest structure, physiognomy, and floristics," Journal of Ecology, vol. 51, no. 3, pp. 567-601, 1963.

[63] K. Yeshitela and T. Bekele, "The woody species composition and structure of Masha-Andederacha forest, southwestern Ethiopia," Ethiopia Journal of Biological Science, vol. 2, pp. 31-48, 2003.

[64] D. Denu, "Floristic composition and ecological study of Bibita forest (Gura Ferda), southwest Ethiopia," Doctoral dissertation, Addis Ababa University, Addis Ababa, Ethiopia, 2006.

[65] E. Lulekal, E. Kelbessa, T. Bekele, and H. Yineger, "Plant species composition and structure of the mana Angetu moist montane forest, south-eastern Ethiopia," Journal of East African Natural History, vol. 97, no. 2, pp. 165-185, 2008.

[66] F. Kenea, "Remnant vegetation and population structure of woody species of Jima forest, western Ethiopia," M.Sc. thesis, Addis Ababa University, Addis Ababa, Ethiopia, 2008.

[67] W. Enkossa, "Floristic analysis of Alata-Bolale forest in Gudaya Billa Woreda, east Wollega, Oromia regional state, west Ethiopia," M.Sc. thesis, Addis Ababa University, Addis Ababa, Ethiopia, 2008.

[68] F. Gurmessa, T. Soromessa, and E. Kelbessa, "Structure and regeneration status of Komto afromontane moist forest, east Wollega zone, west Ethiopia," Journal of Forestry Research, vol. 23, no. 2, pp. 205-216, 2012.

[69] T. Burju, K. Hundera, and E. Kelbessa, "Floristic composition and structural analysis of Jibat humid afromontane forest, west Shewa zone, Oromia national regional state, Ethiopia," Ethiopian Journal of Education and Sciences, vol. 8, no. 2, pp. 11-34, 2013.

[70] K. Aliyi, K. Hundera, and G. Dalle, "Floristic composition, vegetation structure and regeneration status of Kimphe Lafa natural forest, Oromia regional state, west Arsi, Ethiopia," Research \& Reviews: A Journal of Life Sciences, vol. 5, no. 1, pp. 19-32, 2015.

[71] T. T. Tura, T. Soromessa, S. Leta, and M. Argaw, "Plant community composition and structure of asabot dry Afromontane forest, west Harare zone, Ethiopia," Journal of Biodiversity \& Endangered Species, vol. 5, no. 202, p. 2, 2017.

[72] M. Woldearegay, Z. Woldu, and E. Lulekal, "Species diversity, population structure and regeneration status of woody plants in Yegof dry Afromontane forest, Northeastern Ethiopia," European Journal of Advanced Research in Biological and Life Sciences, vol. 6, no. 4, 2018.

[73] H. Zegeye, D. Teketay, and E. Kelbessa, "Diversity, regeneration status and socio-economic importance of the vegetation in the islands of lake Ziway, south-central Ethiopia," Flora-Morphology, Distribution, Functional Ecology of Plants, vol. 201, no. 6, pp. 483-498, 2006.

[74] L. Birhanu, T. Bekele, and S. Demissew, "Woody species composition and structure of Amoro forest in west Gojjam zone, north western Ethiopia," Journal of Ecology and the Natural Environment, vol. 10, no. 4, pp. 53-64, 2018.

[75] A. Girma and R. Mosandl, "Structure and potential regeneration of degraded secondary stands in Munessa-Shashemene forest, Ethiopia," Journal of Tropical Forest Science, vol. 24, no. 1, pp. 46-53, 2012.

[76] F. Senbeta, "Biodiversity and ecology of afromontane rainforests with wild Coffea arabica L. populations in Ethiopia," Ecology and Development Series No. 38, Center for Development Research, University of Bonn, Bonn, Germany, 2006.

[77] H. Yineger, E. Kelbessa, T. Bekele, and E. Lulekal, "Floristic composition and structure of the dry Afromontane forest at 
Bale mountains national park, Ethiopia," SINET: Ethiopian Journal of Science, vol. 31, no. 2, pp. 103-120, 2008.

[78] F. O. Ademoh, J. I. Muoghalu, and B. Onwumere, "Temporal pattern of tree community dynamics in a secondary forest in southwestern Nigeria, 29 years after a ground fire," Global Ecology and Conservation, vol. 9, pp. 148-170, 2017.

[79] D. S. Rawat, S. S. Dash, B. K. Sinha, V. Kumar, A. Banerjee, and P. Singh, "Community structure and regeneration status of tree species in eastern Himalaya: a case study from Neora valley national park, West Bengal, India," Taiwania, vol. 63, no. 1, pp. 16-24, 2018.

[80] S. C. Sahu, N. K. Dhal, and R. C. Mohanty, "Tree species diversity, distribution and population structure in a tropical dry deciduous forest of Malyagiri hill ranges, Eastern Ghats, India," Tropical Ecology, vol. 53, no. 2, pp. 163-168, 2012.

[81] G. Nebel, L. P. Kvist, J. K. Vanclay, H. Christensen, L. Freitas, and J. Rúiz, "Structure and floristic compostion of flood plain forests in the Peruvian Amazon I. Overstoery," Forest Ecology and Management, vol. 150, no. 1-2, pp. 27-57, 2001.

[82] M. Didita, "Floristic analysis of the woodland vegetation around Dello Menna, southeast Ethiopia," M.Sc. thesis, Addis Ababa University, Addis Ababa, Ethiopia, 2007.

[83] E. K. K. Jew, A. J. Dougill, S. M. Sallu, J. O'Connell, and T. G. Benton, "Miombo woodland under threat: consequences for tree diversity and carbon storage," Forest Ecology and Management, vol. 361, pp. 144-153, 2016.

[84] M. Sarkar and A. Devi, "Assessment of diversity, population structure and regeneration status of tree species in Hollongapar Gibbon Wildlife Sanctuary, Assam, northeast India," Tropical Plant Research, vol. 1, no. 2, pp. 26-36, 2014.

[85] T. Demel, "Seed and regeneration ecology in dry Afromontane forests of Ethiopia: I. Seed production-population structures," Tropical Ecology, vol. 46, no. 1, pp. 29-44, 2005.

[86] M. Didita, S. Nemomissa, and T. W. Gole, "Floristic and structural analysis of the woodland vegetation around Dello Menna, southeast Ethiopia," Journal of Forestry Research, vol. 21, no. 4, pp. 395-408, 2010.

[87] T. Bekele, Vegetation Ecology of Remnant Afromontane Forests on the Central Plateau of Shewa, Ethiopia, Opulus Press, Shewa, Ethiopia, 1993.

[88] B. Kebede, "Floristic composition and structural analysis of gedo dry evergreen Montane forest, west Shewa zone of Oromia national regional state, central Ethiopia," Doctoral dissertation, Addis Ababa University, Addis Ababa, Ethiopia, 2010.

[89] S. Alemu, M. Argaw, and E. Kelebisa, Woody Species Composition, Diversity and Structural Analysis of Angada Forest in MertiWereda, Arsi Zone of Oromia Region, Ethiopia, Addis Ababa University, Addis Ababa, Ethiopia, 2011.

[90] A. Ayanaw and G. Dalle, "Woody species diversity, structure, and regeneration status of Yemrehane Kirstos church forest of Lasta Woreda, north Wollo zone, Amhara region, Ethiopia," International Journal of Forestry Research, vol. 2018, Article ID 5302523, 8 pages, 2018.

[91] L. Kumsa, "Floristic composition and structure of GuraLopho moist Afromontane forest, Horo-Guduru Wollega zone, Oromia national regional state, west Ethiopia," M.Sc. thesis, Addis Ababa University, Addis Ababa, 2010.

[92] T. Atsbha, A. B. Desta, and T. Zewdu, "Woody species diversity, population structure, and regeneration status in the Gra-Kahsu natural vegetation, southern Tigray of Ethiopia," Heliyon, vol. 5, no. 1, Article ID e01120, 2019.

[93] D. Premavani, M. T. Naidu, and M. Venkaiah, "Tree species diversity and population structure in the tropical forests of north central Eastern Ghats, India," Notulae Scientia Biologicae, vol. 6, no. 4, pp. 448-453, 2014.

[94] J. T. Curtis and R. P. McIntosh, "An upland forest continuum in the prairie-forest border region of Wisconsin," Ecology, vol. 32, no. 3, pp. 476-496, 1951.

[95] I. S. Miranda, M. L. Absy, and G. H. Rebêlo, "Community structure of woody plants of Roraima savannahs, Brazil," Plant Ecology, vol. 164, no. 1, pp. 109-123, 2003.

[96] G. Bekele, "Floristic composition and structure of the vegetation of Magada forest, Borana zone, Oromia national regional state," M.Sc. thesis, Addis Ababa University, Addis Ababa, Ethiopia, 2005.

[97] S. Shibru and G. Balcha, "Composition, structure and regeneration status of woody species in Dindin natural forest, southeast Ethiopia: an implication for conservation," Ethiopian Journal of Biological Sciences, vol. 1, no. 3, pp. 15-35, 2004.

[98] T. Gemechu, "Floristic composition and structure of gendo (gura tirigni) moist Montane forest, east Wollega zone, Oromia region, Ethiopia," Doctoral dissertation, Addis Ababa University, Addis Ababa, Ethiopia, 2009. 